\title{
$16: 342465-277441$
}

National Cancer Institute

\section{Source}

National Cancer Institute. 16:342465-277441. NCI Thesaurus. Code C41734.

Physical location of AXIN1_Gene 